\title{
CROSS-BORDER CO-OPERATION IN THE EUROREGIONS AT THE POLISH-CZECH AND POLISH-SLOVAK BORDERS
}

\author{
Sylwia Dołzbłasz ${ }^{1}$
}

Received 18 January 2013; Accepted 12 April 2013

\begin{abstract}
The paper deals with border regions in Poland, which are regarded as a specific type of peripheral areas. The aim of this paper was to assess the Polish-Czech and Polish-Slovak border cooperation at the local level and to compare it to the PolishGerman border. The studies were based on the analysis of the microprojects qualified for implementation under the Microprojects Fund within INTERREG IIIA programmes. Particular emphasis was put on the type characteristic of the projects and institutional structure of beneficiaries. Moreover, the relationships between analysed features were studied. The spatial distribution of projects was also examined. The role of Euroregions in the process of cross-border co-operation implementation was described. The analysis of the microprojects was carried out for the Poland's southern border and the western one, as well as for particular Euroregions.
\end{abstract}

Key Words: cross-border cooperation, border areas, Euroregions, microprojects, Interreg, peripheral areas, transborder relations

\begin{abstract}
Artykuł podejmuje problematykę polskich regionów przygranicznych, które są postrzegane jako specyficzny typ obszarów peryferyjnych. Celem opracowania była ocena polsko-czeskiej i polsko-słowackiej współpracy transgranicznej prowadzonej na szczeblu lokalnym. Wyniki były odniesione do współpracy realizowanej na granicy polsko-niemieckiej. Badanie oparte było o analizę mikroprojektów zakwalifikowanych do implementacji w ramach Funduszu Mikroprojektów programów INTERREG IIIA. Szczególną uwagę zwrócono na strukturę rodzajową projektów, a także strukturę beneficjentów. Ponadto analizie poddano wzajemne zależności między poszczególnymi cechami oraz rozmieszczenie przestrzenne mikroprojektów. Przedstawiono również rolę euroregionów w procesie realizacji współpracy transgranicznej. Analiza mikroprojektów przeprowadzona została zarówno w podziale na polską granicę południową i zachodnią, jak i według poszczególnych euroregionów.
\end{abstract}

Słowa kluczowe: współpraca transgraniczna, obszary przygraniczne, euroregiony, mikroprojekty, Interreg, obszary peryferyjne, relacje transgraniczne.

\footnotetext{
${ }^{1}$ Dr. Sylwia Dołzbłasz, Department of Spatial Management, Institute of Geography and Regional Development, University of Wrocław, PI. Uniwersytecki 1, 50-138 Wrocław, Poland; e-mail: sylwia.dolzblasz@uni.wroc.pl
} 


\section{Introduction}

By their nature borderlands constitute peripheral areas, usually characterized by limited transport accessibility and the occurrence of spatial barriers, unfavourable demographic structure, or the dominance of rural areas. The peripheral location of border regions usually causes their 'underdevelopment' (Zapletalová, 2005; Roper, 2007).The development of crossborder co-operation should play significant role in the process of overcoming peripheriality of border areas (Krätke, 1999; Cappellin, 1993). In Europe, special programmes supporting transborder relationships (e.g. Phare CBC, Interreg) as well as the formation and functioning of Euroregions played an important role in the process of intensifying co-operation between partners from regions separated by a state border (Perkmann, 1999; Church and Reid, 1996).

Institutional-organizational structures called Euroregions are located along most national borders in Europe. They appeared as some sort of link between neighbouring countries, and above all between their border regions. Their formation and functioning is the manifestation of the awareness of shared problems and needs as well as a means of intensifying cross-border co-operation. Thus, the role of Euroregions was to help overcome unfavourable features of the location as well as help take advantage of the positive features of cross-border regions. The achievement of fully integrated regions or 'space of transition' (Newman, 2006) proved to be very hard and was very rarely completed. Nevertheless, the value of Euroregions cannot be underestimated and although it wasn't possible to create transboundary border regions in the full sense of the word, they helped tighten co-operation and bring together the areas of the common border regions in the social, economic, infrastructural and tourist spheres. Moreover, Euroregions contributed to the creation of a network of intraregional co-operation, both among self-government institutions as well as other institutions operating in the region. Euroregions fulfilled cardinal function which is development of interpersonal relation and mutual learning of people from two sides of the border and, as a result, overcoming mistrust and better orientation in the neigbouring country (Vaishar, 2008). Research into co-operation is done mainly on a national scale. The actual co-operation, however, depends largely on regional and local conditions and, among other things, Euroregions functioning (Scott, 1999), which is the reason for focusing on their role in this study.

The basic objective of this paper was to assess cross-border co-operation realization under Microproject Fund ${ }^{2}$ within Interreg III A Poland - Czech Republic and Poland - Slovak Republic programmes and its comparison with Polish-German programmes. The aim of the study was also to compare the character of co-operation in particular Euroregions along Polish southern and western border. Special attention was paid to the type characterization of the projects and institutional structure of beneficiaries. Another important objective was to analyse the relationships between spatial distribution of the realized microprojects. Moreover, the hypothesis assuming that the environment conditions (especially mountainous character of Polish-Czech and Polish-Slovak border areas) affect the realization of co-operation at the local level was verified. It has to be stressed that this paper has mainly empirical character.

The research comprises the data concerning all the microprojects realized under Microprojects Fund within Interreg III A Programmes 2004-2006 on the Polish-Czech, Polish-Slovak and Polish-German border ${ }^{3}$. The data was obtained from particular Euroregions, which were responsible for implementation of Small Project Fund. Analysis concerns only projects realized by Polish beneficiaries. The projects of Technical Assistance have been omitted since they are not directly connected with cross-border co-operation.

The author is fully aware that the small projects do not cover the full spectrum of cross-border co-operation. Nevertheless, they constitute its substantial element and reflect the shape of cross-border co-operation at the local level and not declarative co-operation existing only "on paper". The analysis does not cover so called 'large' Interreg projects and informal co-operation. It seems, however, that the analysis of small projects is significant when investigating transborder relationships, as it presents co-operation at the local level, which, due to low

\footnotetext{
2 The term 'Small Projects Fund' is also used for this type of funding.

${ }^{3}$ The data from Euroregion Cieszyn Silesia was not available and projects realized in this Euroregion were not included in the analysis.
} 
entrance barriers, could be realized even by small entities with simple organizational structures located in the borderland. The author is aware that when analysing the cooperation projects, it would be advisable to study their effects (especially long-term). However, this requires a separate, in-depth research and will be the subject of further studies.

An analysis of Interreg IIIA microprojects is closely connected with the functioning of Euroregions, as these units were responsible for implementation of Microprojects Fund. Therefore, the analysis of the projects was carried out for the southern border (Polish-Czech and Polish-Slovak) and the western one (Polish-German), as well as for particular Euroregions.

\section{Development of cross-border co-operation programmes in Poland - formal, legal and financial determinants}

Euroregions have existed in Europe for half a century. However, in Poland and other countries of Central and Eastern Europe they started to appear only after the 1989 transformation. Before, their activity was not possible as these structures are strictly connected with the democratic system and territorial self-government. The first Euroregions in Poland appeared at the Polish-German and Polish-Czech border and therefore they have the widest experience among all the 18 euroregions in the country. It has to be stressed that the first Euroregion created in Poland was trilateral Euroregion Neisse-Nysa-Nisa at the Polish-Czech-German border established in 1991. Moreover, this Euroregion is one of the best functioning and most appreciated units in the Polish borderland.

The development of Euroregions was spurred by the introduction of the Phare CBC programme in Poland. It was a part of the PHARE programme established in order to support the socioeconomic changes started in 1989 in the countries of Central and Eastern Europe (OJ L 375, 23.12.1989, p. 11). The Phare sub-programme Phare Cross-border Co-operation (Phare CBC) came into existence in 1994. The purpose of this programme was to promote co-operation between border regions in order to overcome specific developmental problems, promote the creation of co-operation systems on both sides of the border as well as prepare for the integration with the EU. Among the projects eligible for financing were: eliminating administrative and institutional obstacles in the free flow of people, products or services across the border; improvement in infrastructure; environmental protection; support in energy and transport sectors; promotion of economic co-operation; cultural exchange; initiatives connected with local employment, education and trainings; border area development plans.

The Phare CBC Programme was implemented year by year in accordance with the sequence of the Interreg Initiative editions i.e. 1994-1999 and 2000-2006. In the case of Poland it was till 2004 , i.e. to the moment of our accession to the EU. The implementation of the programme was realized in border regions belonging to particular states (e.g. Poland-Germany, PolandCzechia). The unit managing the programme on the national scale in Poland was the Implementing Authority for Phare Cross-Border Programme. Direct management was conducted by the regional authorities of bordering voivodships. An important role in the implementation of the Phare CBC was played by Euroregions, which were entrusted with the management of the Small Project Fund (SPF) - the projects with the maximum budget of EUR 50.000 and so-called medium-sized projects - maximum budget of EUR 300.000. The Implementing Authority for European Programmes (WWPE) was responsible for managing the SPF but according to the subsidiarity rule it delegated a considerable part of its competences to Euroregions and they practically managed the Fund on their own. The formal management structure was the Steering Committee (consisting of representatives of the most important organizations acting in the region as a watchdog, a representative of WWPE and European Commission Representation) as well as the Euroregion Secretariat (they participated in transferring small subsidies by organizing application competitions, participation in application selection, management of the funds, etc.).

Between 1994 and 2003 almost $20 \%$ of overall Phare budget for Poland was earmarked for Phare CBC (see Report..., 2007). The vast majority of the Phare CBC funds were spent on large investment projects - about $75 \%$ of the funds were allocated to transport and environment protection. The total allocation exceeded EUR 527 mio, almost $97 \%$ of which was absorbed. 
Over 350 projects were executed (excluding 'small' projects) to the total sum of EUR 510mio. We can observe a clear dominance of the western border. The Polish-German programmes during the whole realization period of Phare CBC received considerably higher allocation than the programmes at other borders (EUR $451 \mathrm{mio}$ from total allocation of EUR 527mio). The absorption of the funds in each year was very high, which indicates both significant interest on the part of beneficiaries, as well as the effectiveness of the structures managing the programmes.

Accession of Poland, as well as its southern neighbouring countries, to the European Union in 2004, brought about significant changes in institutional settings of cross-border co-operation. Poland's accession to the EU resulted in covering border areas with 7 Interreg III A programmes, including 2 at the Polish southern border and 3 at the Polish western border (Tab. 1). In Poland allocation to Interreg IIIA programmes was about EUR 149mio (a lot more was allocated to the western border for Polish-German programmes than for Poland' southern border). From these funds, apart from "large projects" which dominate, microprojects under SPF were also executed (allocation about 15\%). Their beneficiaries could be institutions of the same type as in Phare CBC.

\begin{tabular}{|l|l|c|}
\hline \multicolumn{1}{|c|}{ Border } & \multicolumn{1}{|c|}{ Programme } & $\begin{array}{c}\text { Allocation for } \\
\text { Polish side (EUR } \\
\text { in million) }\end{array}$ \\
\hline $\begin{array}{l}\text { Poland's southern } \\
\text { border }\end{array}$ & Poland-Czechia & 18 \\
\cline { 2 - 3 } $\begin{array}{l}\text { Poland's western } \\
\text { border }\end{array}$ & $\begin{array}{l}\text { Poland-Slovakia } \\
\text { Mecklenburg-Vorpommern/Brandenburg; } \\
\text { Poland (Voivodship Lubuskie) - Brandenburg; } \\
\text { Poland (Voivodship Dolnośląskie) - Saxony }\end{array}$ & 10.5 \\
\hline
\end{tabular}

Tab 1. Polish-Czech, Polish-Slovak and Polish-German Interreg IIIA programmes. Source: own study based on data from the Ministry of Regional Development.

The launch of the Interreg implementation induced changes to the institutional-legal forms of cross-border co-operation used so far. Among the most conspicuous differences between Interreg and Phare CBC were: the necessity to create joint, e.g. Polish-Czech, Polish-German structures, long-term budget (as opposed to the annual one), the rule of cost reimbursement, and no advance payment system. The Microproject Fund was included into Interreg III A transborder programmes and was one of the measures, most often within priority 'Development of local communities'/ 'Support for local initiatives'. As far as Euroregions are concerned, they retained their responsibility for the Microproject Fund. In the financial context, the situation was very similar and Euroregions received funds for management comparable to those in the Phare $\mathrm{CBC}$. The requirement of belonging to Euroregions was done away with, as the eligible areas were defined on the basis of NUTS 3 classification. It may lead to resignation from participation in euro-regional associations and the necessity to seek new elements attracting territorial units to membership, since the launch of Interreg, the funds can be obtained directly. However, Euroregions still manage Microproject Fund and play the most important role as for implementation of undertakings within this measure.

The main aim of Euroregions is to develop and reinforce co-operation between communities on both sides of the border with the view to achieving common goals in the field of culture, education as well as in the social and economic spheres. It seems that microprojects are necessary for the development of transborder co-operation as they directly concern local communities and institutions in the borderland. The results of these projects should contribute to reinforcing their mutual contacts. Close co-operation between people living in the borderland will help deepen good neighbourly relations and additionally may create the basis for bigger, joint transborder projects. The participation of Polish partners in microprojects is co-financed from the European Regional Development Fund to the value of up to $75 \%$ of the qualified expenses incurred and varies from 2-20k EUR. The remaining $25 \%$ of the budget comes from the state sources (mainly local and regional ones). The funds are transferred in the form of 
reimbursement of the costs incurred. Additionally, Polish partners involved in the realization of microprojects may apply for subsidies from the state budget, via an appropriate Euroregion, which can constitute up to $10 \%$ of the total qualified costs of the project. The share of the Microprojects Fund usually constituted $15 \%$ of the total programme. Allocation for particular Euroregions was 0.5 - 2mio EUR (Implementing Authority for European Programmes).

\begin{tabular}{|l|l|}
\hline Areas & Typical projects \\
\hline $\begin{array}{l}\text { Economic and tourist } \\
\text { development }\end{array}$ & $\begin{array}{l}\text { Co-operational fairs, trading events, trainings for entrepreneurs and farmers, } \\
\text { joint promotional activities, publishing materials, mapping out and marking } \\
\text { tourist trails and tourist attractions in towns and communes }\end{array}$ \\
\hline Cultural exchange & $\begin{array}{l}\text { Jubilee celebrations in towns and communes; music, folk, theatre and film } \\
\text { festivals, mass events, festivities, sports competitions, rallies, open-air art } \\
\text { workshops, exhibitions, publications }\end{array}$ \\
\hline $\begin{array}{l}\text { Development of local } \\
\text { democracy }\end{array}$ & $\begin{array}{l}\text { Meetings and exchange programmes for self-government officials as well as } \\
\text { representatives of various social and trade groups, conferences, seminars, } \\
\text { trainings on self-government, integration, trans-border co-operation }\end{array}$ \\
\hline $\begin{array}{l}\text { Development of } \\
\text { human resources }\end{array}$ & $\begin{array}{l}\text { Seminars, conferences, symposia and academic sessions, trainings, } \\
\text { workshops, joint training for particular services (fire and rescue service, } \\
\text { border guards) prophylaxis and prevention programmes, publications, } \\
\text { rehabilitation/ education camps }\end{array}$ \\
\hline $\begin{array}{l}\text { Trans-border studies } \\
\text { and developmental } \\
\text { concepts }\end{array}$ & $\begin{array}{l}\text { Drawing up studies, analyses and concepts as well as conducting } \\
\text { researches with specially formed international working groups }\end{array}$ \\
\hline $\begin{array}{l}\text { Environmental } \\
\text { protection }\end{array}$ & $\begin{array}{l}\text { Pro-ecological activities - cleaning and afforestation campaigns, ecological } \\
\text { education, creating films and publications connected with ecology }\end{array}$ \\
\hline
\end{tabular}

Tab 2. The main areas of support under SPF. Source: own study based on data from the Implementing Authority for European Programmes.

Microprojects funds were earmarked mainly for creating 'interpersonal trans-border bonds and connections' (Tab. 2). The main objectives included: promotion of co-operation between border regions and consequently assistance in overcoming specific developmental problems for the benefit of inhabitants and in accordance with the requirements of environmental protection; promotion of creating and development of a co-operation network on both sides of the border and connections with wider networks within the EU. Beneficiaries of Microprojects Fund could only be non-profit institutions - territorial self-governance units, unions and inter-commune associations, chambers of commerce, professional associations, Euroregions, community cultural centres, sports and recreation centres, sports clubs, cultural institutions and other nonprofit institutions.

\section{Determinants of cross-border co-operation on the southern border of Poland}

When analysing determinants of the role of the state border, it needs to be remembered that although its obvious material implications are important, a borderland is shaped by a whole set of cultural, historical and political interactions and processes occurring within its space (van Houtum, 1999). Similarly, transborder co-operation, with its complex character, is determined not only by institutional, and financial factors, but also by factors specific to particular regions (Dołzbłasz \& Raczyk, 2012). Among the most important ones are disparities in the level of socio-economic development on both sides of the border. It seems that the high level of disproportions is an important factor hindering co-operation. It results, among other things, from different expectations concerning potential co-operation. In this respect, the Polish-Czech and Polish-Slovak border areas are regions with relatively low level of disparities. In contrast, the Polish-German border is believed to be one of the internal EU borders characterized by the highest level of economic disparities (see ESPON Atlas, 2006; Topaloglou et al., 2005).

Similarity of problems and objectives regarding socio-economic development is a crucial determinant shaping co-operation. Also, in this respect some similarities with the Polish-Czech and Polish-Slovak border region can be observed in relation to the encountered problems, e.g. the occurrence of problem areas, i.e. negative demographic structures in the countryside 
(Pokluda, 2005), joint mountain region, reorganization of traditional branches of industry. But joint objectives can be noticed as well as, e.g. integration with the EU, economic development, search for activation incentives, tourism development. At the Polish-Czech border we can observe considerable economic potential, similar economic structures, but at the same time a number of developmental problems (problem areas) (Belof et al., 2008). It needs to be stressed that the cultural barrier was smaller at the southern border than that at the western border of Poland with Germany, e.g. the persistence of stereotypes, attitude towards neighbouring nations, historical experiences, etc. (although its significance seems to be decreasing (Krätke, 2002).

In both cases the border was established on the basis of environmental features. The southern border is running mainly across mountainous region, while Polish-German border is mostly the river border (it results in relatively low number of border crossings. Furthermore, transportation is also made difficult by the fact that in most cases the connections require bridge crossings). The southern border, due to its mountainous character, constitutes a significant impediment affecting free movement of people and goods, because it restricts the freedom of border crossing (Więckowski, 2004). However, a relatively high number of border crossings to Czechia, over 100, and over 50 to Slovakia, including border crossings only for small border traffic and on the tourist trails (data for 20.12.2007 just before joining the Schengen Zone) greatly facilitates local traffic at the southern border. Since Poland's, the Czech Republic's and the Slovak Republic's entering the Schengen Zone (2007) there are virtually no formal barriers for the flow of people. This significantly facilitates local traffic (especially pedestrian and cycling traffic). It needs to be remembered that there are very few good quality roads: those which lead to border crossings (only one motorway connection) and additionally limited by such factors as weather conditions, especially in winter. The structure of transport connections is still unfavourable and requires further improvement (Michniak, 2010; Vaishar (ed.), 2012; Więckowski et al., 2012; Studium zagospodarowania pogranicza polsko-czeskiego, 2006).

The character of co-operation in the Polish-Czech and Polish-Slovak border region is determined to a great extent by environmental determinants and is highly affected by the borders' location in touristy areas (mountain tourism, winter sports, a great number of historical buildings) as well as great natural value of the region (numerous national and landscape parks). It not only facilitates but also 'determines' potential directions of co-operation, in accordance with the unique character of the area. Consequently, there is greater potential for integration in this border region. At the same time, it may be connected with the creation and consolidation of 'co-operation monoculture' dominated by tourist-oriented activities. However, the occurrence of a clear integrating factor in the border region may create favourable conditions for the creation of a truly trans-border region (Dołzbłasz and Raczyk, 2010).

\section{Cross-border co-operation at the local level in the Polish-Czech and Polish-Slovak border area}

The funds allocated for small projects within cross-border programmes in Poland have been fully utilised. Therefore, from the practical point of view, the programme turned out to be a success. What's also important, potential beneficiaries displayed significant interest in the project. This shows that the activity period between 2004 - 2006 played a significant role in propagating co-operation at the local level within Poland's southern and western border regions.

The number of realised projects depended on the extent of financial support available within the specific programmes. The funds allocation (in per cent) was the same, but the amount of money available differed as Polish-German programmes had much higher allocation compared to Polish-Czech and Polish-Slovak ones. Subsidies for Microprojects Fund from particular transborder programmes were distributed among Euroregions from the given area. In consequence, for the Euroregions at the southern border the allocation was lower, at the western border funds were higher and as a result the share of small projects realized in Euroregions at the Polish-German border (Pomerania, Pro Europa Viadrina, Spree-NeisseBober) was significantly higher (Fig. 1). The share of projects realized in the Euroregion NeisseNysa-Nisa, which is situated at both borders, were higher than in bilateral Euroregions at 
the southern border (37\% of the projects in Euroregion Neisse-Nysa-Nisa was realized within the Poland-Czech cross-border programme and $73 \%$ within the Poland-Saxony programme).

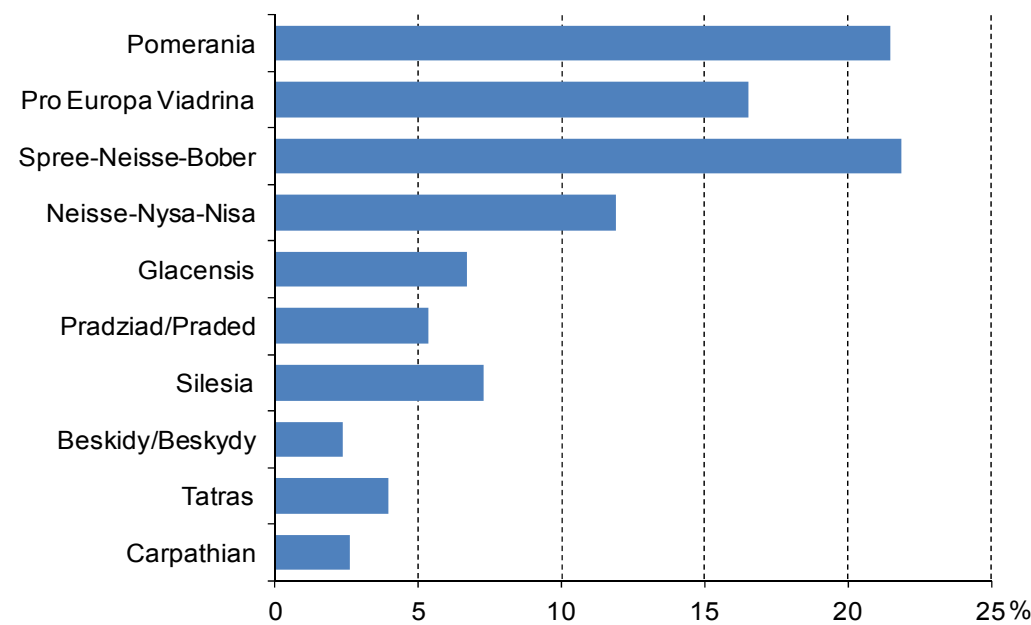

Fig 1. The share of microprojects realized in particular Euroregions in the total number of microprojects within Interreg III A in the Polish part of the Polish-Czech, Polish-Slovak and Polish-German borderlands. Source: own elaboration based on the data from Euroregions.

Due to similar institutional structure and legal conditioning, the types of projects executed didn't differ significantly. Within the most basic division according to intervention category (Fig. 2) a similarity was observed.

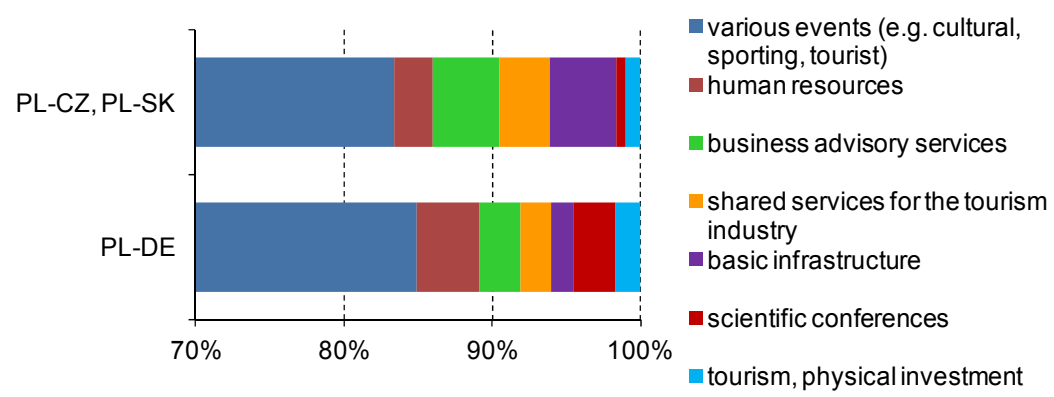

Fig 2. The type structure of microprojects within Interreg III A programmes in the Polish part of the Polish- Czech, Polish-Slovak and Polish-German borderlands. Source: own elaboration based on the data from Euroregions.

The most popular microprojects in all borderlands (Polish-Czech, Polish-Slovak and PolishGerman) were those which aimed at bringing closer the communities from both sides of the border by holding joint transborder events, activities often referred to as „people for people”. This was connected with the main objective of the Microprojects Fund which was to support local initiatives and develop local communities in transborder terms. Usually, these projects were connected with culture in the broad sense. Joint transborder events dominated in the area of all the analysed Euroregions (Fig. 3).

However, differences became apparent when the most popular category ('various events') was analysed in more detail (Tab. 3). In this case the higher share of projects connected with tourism was observed at the southern border. Moreover, the percentage of projects dealing with services for the tourism industry was also double. This resulted from the existence of beneficial natural conditions, which are favourable for tourism, on both sides of the border (Karpaty and Sudety mountains). This indicates that individual conditions for the specific programmes played an important role while being different at each of the borders. 


\begin{tabular}{|l|c|c|c|c|c|}
\hline \multirow{3}{*}{ Border } & \multicolumn{5}{|c|}{ Subcategories of category 172 - Events from the sphere of: } \\
\cline { 2 - 6 } & culture & sport & tourism & education & environment protection \\
\cline { 2 - 6 } & \multicolumn{5}{|c|}{ \% of all projects from the border } \\
\hline southern & 29,7 & 14,0 & 9,6 & 5,2 & 0,4 \\
\hline western & 37,7 & 16,8 & 3,6 & 8,2 & 2,2 \\
\hline
\end{tabular}

Tab 3. The share of microprojects by intervention subcategory 172 „Miscellaneous events”. Source: own elaboration based on the data from Euroregions.

It is worth mentioning that the share of projects from the field of entrepreneurial support in the Polish southern border was twice as big as the share of these projects along our western border. This is probably caused by the fact that at the local level the connections between companies from Poland, Czechia and Slovakia are much stronger than those with companies from Germany.

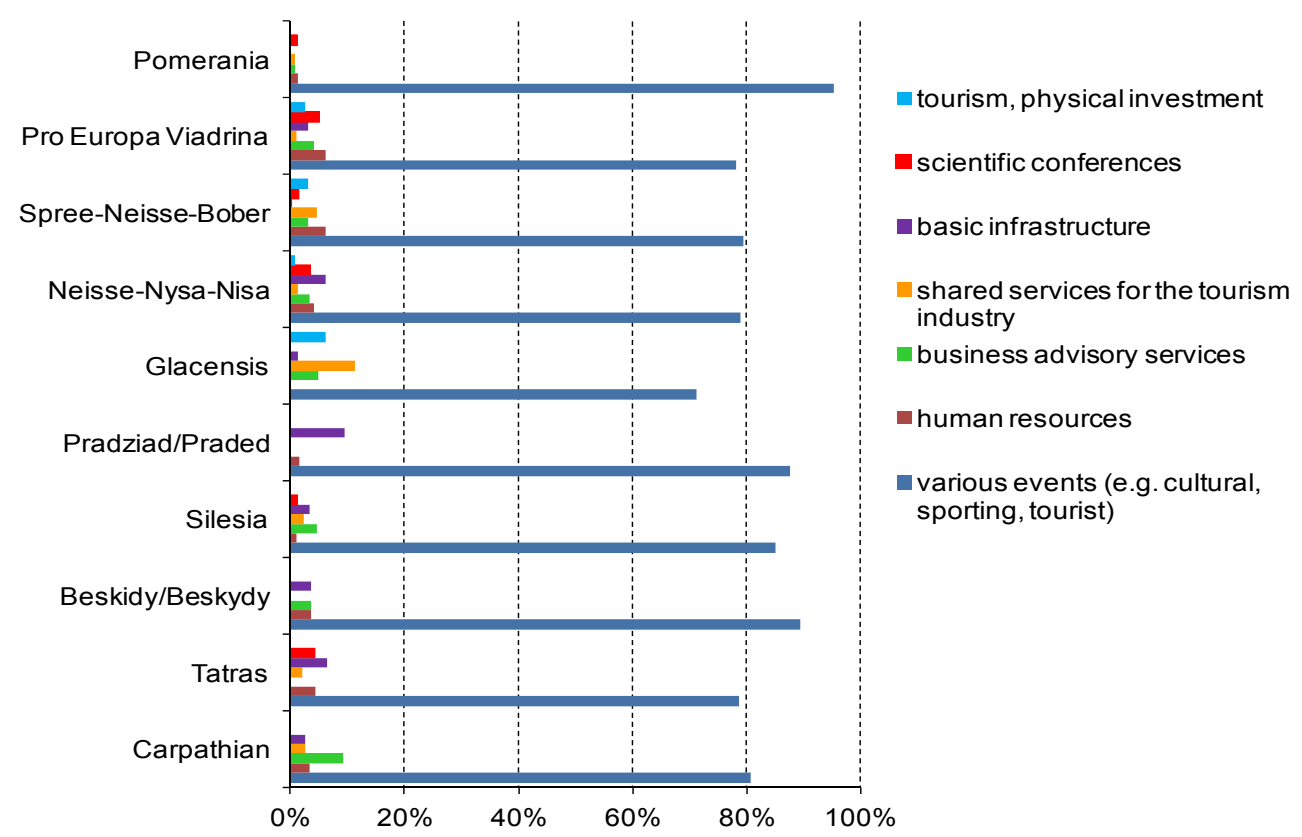

Fig 3. The type structure of microprojects realized in particular Euroregions within Interreg III A programmes in the Polish part of the Polish-Czech, Polish-Slovak and Polish-German borderlands. Source: own elaboration based on the data from Euroregions.

It is worth mentioning that the share of tourist-related projects was the biggest in Euroregions located along Polish southern border - in Euroregion Beskydy it was 14\%, Praded 12\%, and Carpathian $10 \%$ of all the realized projects. The lower share of tourist activities in euroregions at the Polish-German border (only $3 \%$ in the Spree-Neisse-Bober Euroregion) confirms the significance of the location in this respect. Similarly, only in the Polish-Czech Euroregion Glacensis a relatively high percentage (about 10\%) of tourist investment enterprises was noted as well as projects aimed at joint tourist marketing (over $11 \%$ ). With regard to activities oriented towards human resources and educational events, the most active were the Polish-German Euroregions (especially Spree-Neisse-Bober Euroregion). At the southern border a big share of educational events was observed in the area of Beskydy Euroregion (about 18\%). It is also worth noting that in the Carpathian Euroregion there was a considerably high percentage of projects aiming at supporting entrepreneurship (over $9 \%$ of all the projects).

The type structure of microprojects within Interreg III A in the Polish-Czech and Polish-Slovak borderlands was typical of Microprojects Fund which realizes low-budget enterprises. It was dominated by „people for people” type of activities. Their main objective was to integrate borderland communities through getting to know the culture of the neighbours, cherishing common cultural heritage and joint sporting and tourist activities. It needs to be emphasized that great tourist attractions as well as the existence of protected areas in the Polish-Czech and 
Polish-Slovak regions account for higher activity of beneficiaries compared to Polish-German borderland.

The structure of beneficiaries in each Euroregion, as well as compared to southern and western borders, was similar (Fig. 4). There were, however, some discrepancies. Along both analyzed borders the largest share was observed among territorial self-governments with municipality governments strongly dominating. However, in Polish-Czech and Polish-Slovak Euroregions, the share of local government units was over $10 \%$ higher compared to Polish-German borderland, while the activity of NGOs and cultural and recreational institutions was at a lower level. This seems to be the result of better preparation of this type of units from Polish-German borderland for the implementation of transborder activities. Thanks to extensive history of institutional co-operation (Phare CBC programmes already at the beginning of ' 90 s) they had greater experience in implementing transborder enterprises (including long-standing cooperation partners on the German side). Similarly, low level of activity in co-operation was observed in schools, and especially in scientific institutions. This could, however, result from the fact that educational units have the possibility to implement transborder activities (school exchanges, joint research) also within other, dedicated support programmes, as they usually require greater funding than those offered by Interreg III A Microprojects Fund.

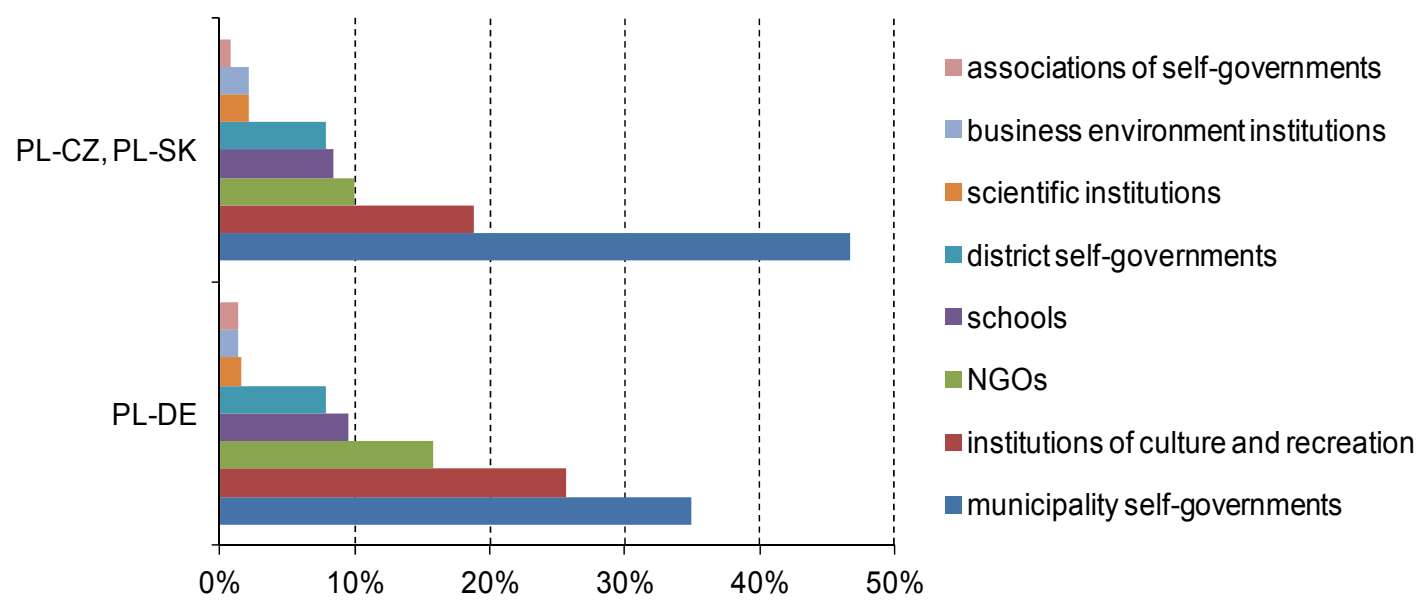

Fig 4. Beneficiary structure of microprojects within Interreg IIIA in the Polish part of the Polish-Czech, Polish-Slovak and Polish-German borderland. Source: own elaboration based on the data from Euroregions.

The relatively high level of activity of schools from Silesia Euroregion is also worth noting. This was probably caused by a high level of urbanization of this region, and, consequently, a large number of primary schools, lower secondary schools and secondary schools. The activity of scientific institutions from Beskydy Euroregion (mainly colleges and university level institutions in Bielsko Biała) was also noticeable.

A very clear dominance of local governments is, on the one hand, a favourable phenomenon, as it means that the communes are actively participating in transborder co-operation. Positive relationships between local governments and partners from the other side of the border not only allow for undertaking joint activities which are beneficial for borderland inhabitants, but also help them use these relationships in other practical spheres of life, which have more measurable effects and bring mutual benefits. It needs to be stressed that territorial units which are the beneficiaries of the microprojects organize events as part of microprojects and engage inhabitants of the communes. Thus, they realize the main objective of the Microprojects Fund, which is bringing together local communities separated by a state border. If the neighbours get to know each other well, it may lead to eliminating negative national stereotypes, establishing economic co-operation, increasing connections between inhabitants, etc. In the long run, it creates favourable conditions for an integrated transborder region. On the other hand, however, much lower level of activity on the part of other institutions (e.g. NGOs, business support institutions) seems to be an alarming phenomenon. This indicates a need to take action aimed at increasing their involvement in transborder co-operation and include them in the co-operation 
network which is continually developing in the borderland. This would allow for better and more effective realization of transborder co-operation objectives using grass-root initiatives.

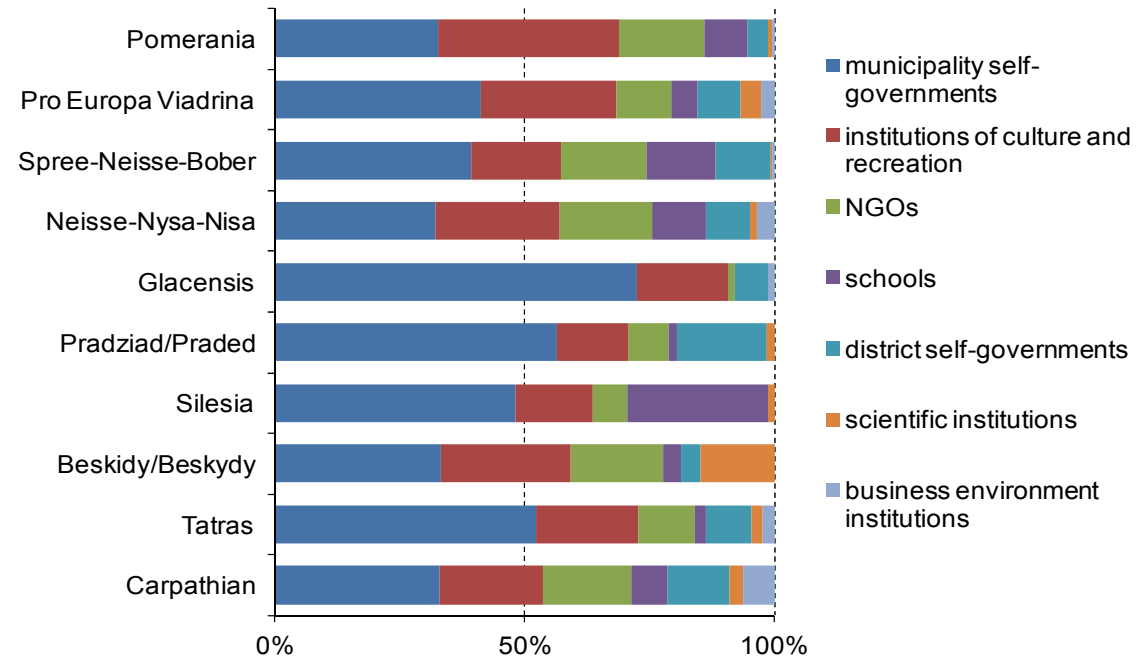

Fig 5. Beneficiary structure of microprojects realized in particular Euroregions under Interreg IIIA in the Polish-Czech, Polish-Slovak and Polish-German borderland. Source: own elaboration based on the data from Euroregions.

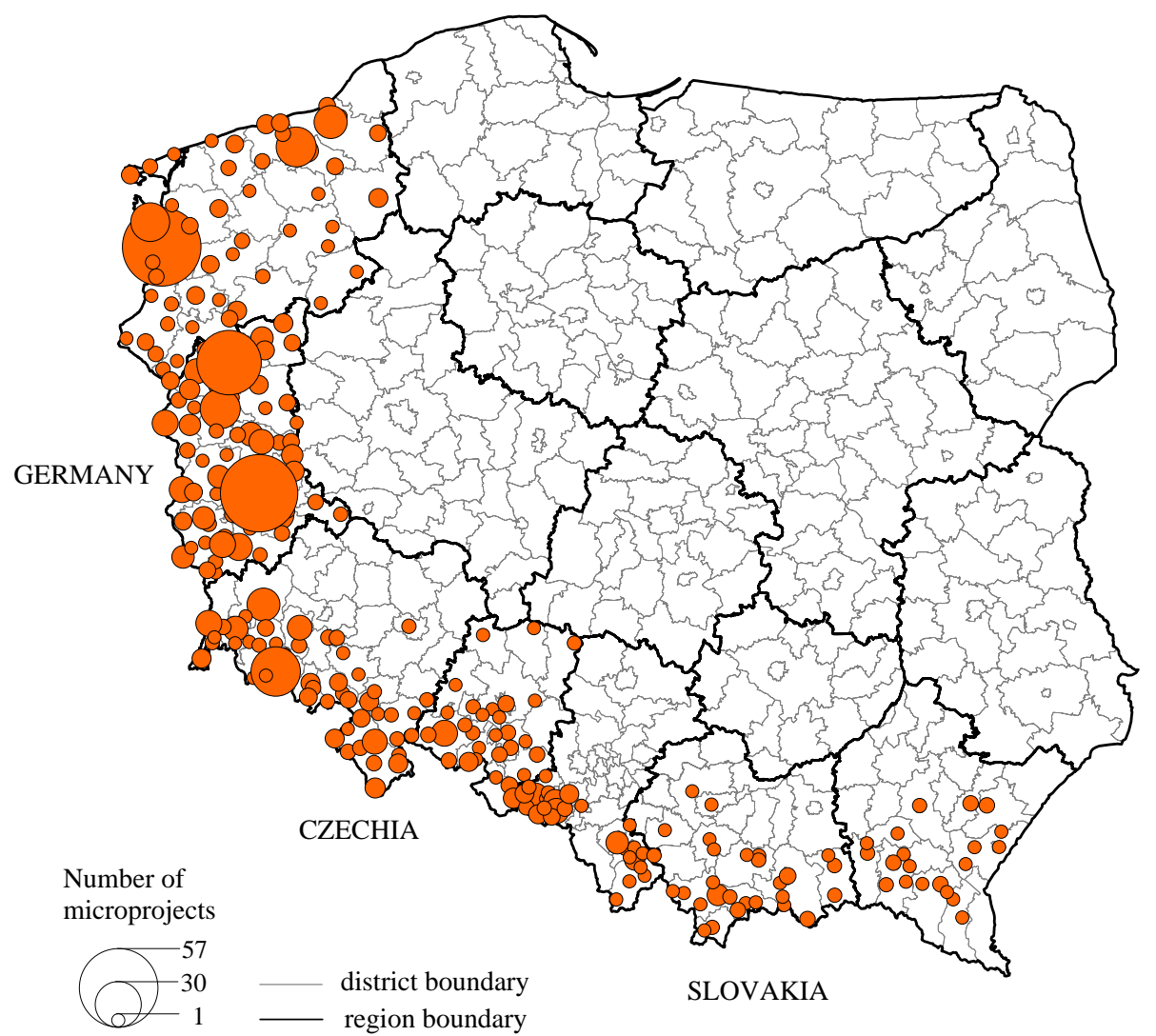

Fig 6. Spatial distribution of microprojects realized under Interreg IIIA in Polish part of the Polish-Czech, PolishSlovak and Polish-German borderland. Source: own elaboration based on the data from Euroregions.

The main factors shaping spatial distribution of the realized microprojects in the southern border area of Poland was the factor of border proximity (Fig. 6). It was clearly visible, especially compared to the western border with Germany where no spatial concentration was observed. Within southern border area itself it seems that in the Polish-Czech part the vicinity of the border played more important role than in areas neighbouring Slovakia. A significant role in spatial distribution was played by tourist attractiveness of particular regions as well as the existence of spa and tourism resorts (the Stołowe Mountains, the Karkonosze Mountains, the Silesian 
Beskid Mountains, Żywiecki Beskid Mountains, Tatra Mountains). There is characteristic concentration of microprojects in Raciborski district and Wodzisławski district (south-western part of Silesia Region), which results from the high activity of urban as well as rural municipalities situated in Euroregion Silesia and direct neighbourhood of well developed Czech areas. Significant activity of beneficiaries from urban municipalities was observed, but it needs to be stressed that they didn't dominated the transborder relations, as rural municipalities participation in microprojects was at a relatively high level. It was probably the result of intentional and active policy of local self-governments. Interestingly, the biggest cities from border areas (such as e.g. Wałbrzych, Bielsko-Biała, Nowy Targ, Nowy Sącz, Krosno, Sanok) played a relatively small role in the shaping of this co-operation despite their location which should encourage high activity.

\section{Conclusion}

Obtaining subsidies for joint Polish-Czech and Polish-Slovak projects from Intrerreg III definitely had a great impact on the development of transborder co-operation in the Polish southern borderland. The successful functioning of Euroregions, whose main aim is to support transborder relationships, favourably contributed to developing this co-operation. In the analyzed period over 1200 joint microprojects were implemented to the amount of about 10mio EUR. Transborder activities took place along the whole course of the Polish-Czech and Polish-Slovak border. The factor of the vicinity of the border played an important role, as in their neighbourhood concentration of the projects increased. The concentration of transborder enterprises was biggest in urban areas. However, they are also realized in rural areas. The dominance of local government units in the beneficiary structure at the commune level signifies that communes were (and still are) the main actors of transborder co-operation at the local level. A similar situation was observed in the Polish-German borderland. This indicates a need to launch activities aiming at activating other institutions, especially associations, schools and business support institutions. Although clear dominance of microprojects in the type structure at the Polish-Czech and Polish-Slovak borders is typical of Microprojects Fund (various types of events), the share of activities connected with environment protection (despite all the natural values of the borderland), the development of human resources, or activities supporting entrepreneurship is still very low. Compared to the Polish-German border, Polish southern border is characterized by much greater share of tourist projects. These include both „meeting” activities as well as joint transborder promotional and marketing activities. It seems that the main objective of Microprojects Fund was achieved, since the great number of cultural, sporting and tourist events provided an opportunity to meet for the inhabitants of Polish-Czech and Polish-Slovak borderlands, as well as for tourists from outside this region. Moreover, it appears that in the long run implementation of joint transborder activities will lead to overcoming negative effects of peripheral location of both borderlands.

\section{Acknowledgement}

The publishing of the paper is supported by the Visegrad Fund, project Nr. 11220149 "Borders and Borderlands within the Central Europe".

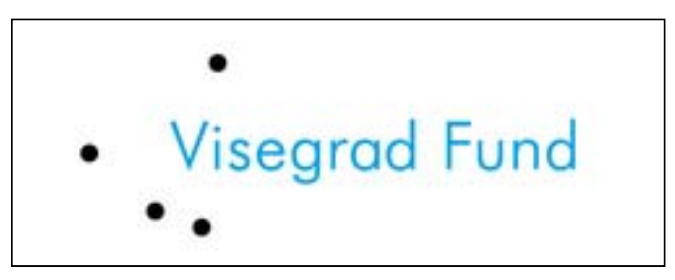


[1] Belof, M. et al. (2008). Uwarunkowania rozwoju przestrzennego Polski wynikające z sąsiedztwa z republiką Czech (pp. 233-274). In Ekspertyzy do KPZK 2008-2033, t. III, Warszawa: Ministerstwo Rozwoju Regionalnego.

[2] Cappellin, R. (1993). Interregional cooperation in Europe: an introduction. In Cappellin, R. \& Batey, P. W. J., eds., Regional Networks, Border Regions and European Integration London: Pion.

[3] Church, A. \& Reid, P. (1996). Power, International Networks and Competition: The Example of Cross-border Cooperation. Urban Studies 33(8), 1297-1318. Doi: $10.1080 / 0042098966664$.

[4] Dołzbłasz, S. \& Raczyk, A. (2010). The role of the integrating factor in the shaping of transborder co-operation: the case of Poland. Quaestiones Geographicae 29(4), 65-73. Doi: 10.2478/v10117-010-0032-3.

[5] Dołzbłasz, S. \& Raczyk, A. (2012). Transborder openness of companies in a divided city. Zgorzelec/Görlitz case study. Tijdschrift voor economische en sociale geografie, Vol. 103, No. 3, 347-361. Doi: 10.1111/j.1467-9663.2011.00688.x.

[6] ESPON Atlas, 2006, Mapping the structure of the European territory, Bonn: Bundesamt für Bauwesen und Ramordnung.

[7] Implementing Authority for European Programmes, http://www.wwpe.gov.pl (access at 10.12.2012).

[8] Krätke, S. (1999). Regional Integration or Fragmentation? The German-Polish Border Region in a New Europe. Regional Studies 33(7), 631-641. Doi: 10.1080/00343409950078675.

[9] Krätke, S. (2002). The Regional Impact of EU Eastern Enlargement: A View from Germany. European Planning Studies 10(5), 651-664. Doi: 10.1080/09654310220145378.

[10] Michniak, D. (2010). Accessibility of selected boundary regions in Slovakia. EUROPA XXI 20, 161-173.

[11] Newman, D. (2006). The lines that continue to separate us: borders in our borderless' world. Progress in Human Geography 30(2), 143-161. Doi: 10.1191/0309132506ph599xx.

[12] OJ L 375, 23.12.1989, Council Regulation (EEC) No 3906/89 of 18 December 1989 on economic aid to the Republic of Hungary and the Polish People's Republic.

[13] Perkmann, M. (1999). Building governance institutions across European borders. Regional Studies, 33 (7), 657-667. Doi: 10.1080/00343409950078693.

[14] Pokluda, F. (2005). Orlicko: a rural microregion on the Czech-Polish state border. EUROPA $X X I, 13,173-184$.

[15] Report on implementation of programmes realized by Implementing Authority for Phare Cross-Border Programme / Implementing Authority for European Programmes, (2007). Implementing Authority for European Programmes, Warsaw, pp. 193.

[16] Roper, S. (2007). Cross-border and local co-operation on the island of Ireland: An economic perspective. Political Geography 26(5), 554-574. Doi: $10.1016 /$ j.polgeo.2007.04.002.

[17] Scott, J.W. (1999). European and North American contexts for cross-border regionalism. Regional Studies 33(7), 605-617. Doi: 10.1080/00343409950078657.

[18] Studium zagospodarowania przestrzennego pogranicza polsko-czeskiego (2006). Warszawa-Wrocław-Praha: Ministerstwo Budownictwa Rzeczypospolitej Polskiej, Ministerstvo pro místní rozvoj České Republiky. 
[19] Topaloglou, L., Kallioras, D., Manetos, P. \& Petrakos, G. (2005). A Border Regions Typology in the Enlarged European Union. Journal of Borderlands Studies 20(2), 67-89. Doi: 10.1080/08865655.2005.9695644.

[20] Vaishar, A. (2008). Possibilities for multifunctional development of rural regions in the Czech borderland. EUROPA XXI 17, 63-70.

[21] Vaishar, A. (ed.) (2011). Regiony v pohraničí. Studia Geographica 103. Brno: Ústav geoniky AV ČR, Mendelova univerzita v Brně.

[22] van Houtum, H. (1999). Internationalisation and mental borders. Tijdschrift voor Economische en Sociale Geografie, 90 (3), 329-335. Doi: 10.1111/1467-9663.00074.

[23] Więckowski, M. (2004). Przyrodnicze uwarunkowania kształtowania się polsko-słowackich więzi transgranicznych. Prace Geograficzne nr 195. Warszawa: IGiPZ PAN.

[24] Więckowski, M. et al. (2012). Pogranicze polsko-słowackie. Dostępność transportowa a turystyka. Warszawa-Bratislawa: IGiPZ PAN, Geografický ústav Slovenská akadémia vied.

[25] Zapletalová, J. (2005). Geography of the Polish - Czech borderland: the case of Euroregion Beskydy. EUROPA XXI 13, 161-172. 